DOI: $10.17516 / 1997-1370-0592$

УДК 330.341 .2

\title{
Institutional Reforms of the Waste Management in the Russian Federation
}

\author{
Tatiana O. Tagaeva* and Vadim M. Gil'mundinov \\ Novosibirsk State University \\ Novosibirsk, Russian Federation \\ Institute of Economics and Industrial Engineering of SB RAS \\ Novosibirsk, Russian Federation
}

Received 08.11.2019, received in revised form 03.03.2020, accepted 13.04.2020

\begin{abstract}
The current status of protection of the natural water and atmospheric resources is assessed as negative, without clear improving tendencies but with a stable pro-cyclical character. Unfortunately, the same cannot be said about the management of production and consumption waste. Even in the stagnation periods, the volume of generated and accumulated waste continues growing. In the year 2018, the first indicator doubled compared to the year 2005. Thus, the urgency of the research is augmented by the unfavourable ecological situation in Russia. The objective of the paper is to develop methodological approaches to the analysis and forecasting of the situation. The objective determined the following targets: to study the current state of the environment regarding the handling of waste, to develop premises to forecast generation and accumulation of waste, to assess the ecological load for the nearest future. Despite the active efforts to reform the waste management system undertaken since 2014, the Russian legislation is imperfect and contradictory in this aspect, not capable of stimulating the processing of waste. The principal contradictions of the ongoing reforms are considered in this paper.
\end{abstract}

Keywords: generation and accumulation of production and consumption waste, municipal solid waste, recycling, utilization and deactivation of waste, environmental legislation.

This paper presents the results of the research financed under the plan of Scientific research of IEIE SB RAS, project XI.170.1.1. "Innovative and ecological aspects of structural transformation of the Russian economy in conditions of new geopolitical reality", No. AAAA-A17-117022250127-8.

Research area: economics and national economy management (economics of environmental management).

Citation: Tagaeva, T.O., Gil'mundinov, V.M. (2020). Institutional reforms of the waste management in the Russian Federation. J. Sib. Fed. Univ. Humanit. Soc. Sci., 13(4), 487-495. DOI: 10.17516/19971370-0592.

\footnotetext{
(C) Siberian Federal University. All rights reserved

* Corresponding author E-mail address: tagaeva@ieie.nsc.ru, gilmundinov@mail.ru ORCID: 0000-0002-9467-6436 (Tagaeva); 0000-0002-1991-0114 (Gil'mundinov)
} 


\section{Introduction}

Despite the economic stagnation, the ecological situation in the Russian Federation remains rather dramatic. As far as the protection of the natural water and atmospheric resources is concerned, there is some positive dynamics (according to Rosstat (Russian Statistics Committee), the annual discharge of contaminated sewage waters fell by $26 \%$ and discharge of air pollutants dropped by $10 \%$ over the period from 2005 to 2018). This is attributed to the crisis-related phenomena in the economy and some legislative restrictions. At the same time, current waste management has brought the ecological situation to a critical level. According to the Russian Public Report on Environmental Protection for 2018, by the end of 2017, the total amount of accumulated and registered production and consumption waste in the country reached about 31.5 billion tons, and 40.7 billion tons ( $29 \%$ more) by the end of 2018 . The volume of waste generation is growing year after year. In 2017, it was 6220.6 while in 2018 it counted 7266.1 million tons $(17 \%$ more, see Fig.1). Waste is one of the reasons same as that of some developed countries in the early nineties. The average level of waste processing in the world is $85-90 \%$, while in the RF it is still below $60 \%$. The level of the municipal solid waste (MSW) processing is even worse. According to Rosstat, the share that goes to processing (waste processing and waste-burning enterprises) does not exceed $10 \%$, whereas in the developed countries it reaches $90 \%$. In the RF, over $90 \%$ of MSW is buried.

Problem statement. The waste management reform appears to have started with the adoption of the Federal Law No. 458-FZ of 29.12.2014 "On amendments to the Federal Law No. 89-FZ of 24.06.98 'About production and consumption waste' and some legislative acts". However, many articles of the Law have not been properly formulated or specified, which in turn required a new law, FZ of 31.12.2017 No. 503-FZ "On amendments to the Federal Law 'About production and consumption waste". In September 2019, the Ministry of Natural Resources and Environment of the Russian Federation published a draft federal law "On amendments to
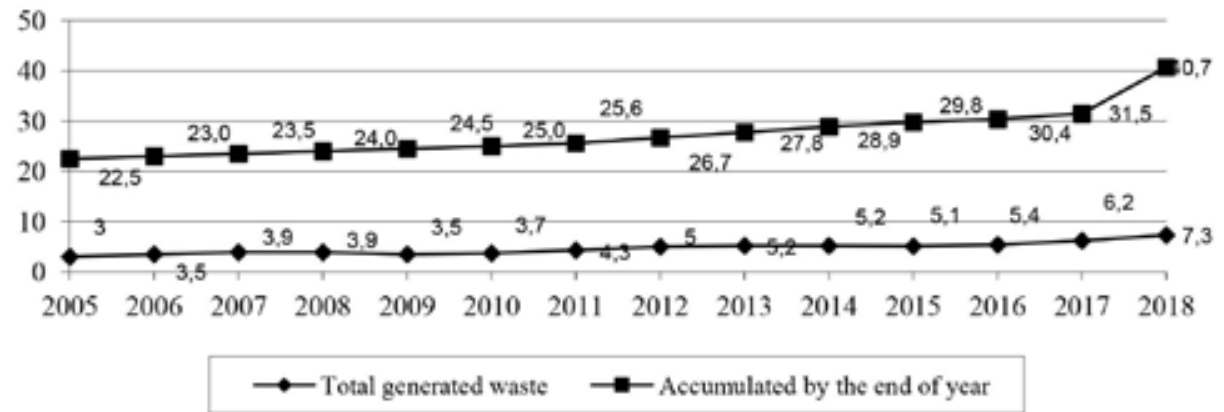

Fig. 1. Dynamics of generation and accumulation of production and consumption waste (bln tons). The source: based on Rosstat data

why natural biochemical cycles are breaking down. The wastes occupy vast territories for storage, produce dangerous toxic elements and dust, and discharge pollutants into the atmosphere, soil, into the ground and underground waters. Regulating these flows is vital to protect the human habitat. The actual waste disposal situation in Russia is the the Federal Law 'About production and consumption waste",.

Besides the principal waste management laws, the legislation has recently adopted several important program documents. In 2018, the Strategy to develop industrial processing, utilization and decontamination of production and consumption waste was approved for the 
period till $2030^{1}$. The Strategy is planned to be implemented in two stages: the first lasting from 2018 to 2021 and the second, from 2022 to 2030. The first stage includes such measures as laying down the required technological and industrial capacity, comprehensive spatial development and design of the location of the enterprises for processing, utilization and decontamination of waste, establishing an equipment certification centre and enforcement of the regulatory norms. The same stage envisages implementing pilot projects of industrial technical facilities for the processing, utilization and decontamination of waste, multi-functional complexes for industrial decontamination and regional eco-techno-parks. The second stage starting in 2022 includes the operation of Russian scientific, technological and industrial infrastructure incorporating hi-tech equipment and machinery for processing, utilization, decontamination of waste and manufacture of products out of salvaged raw materials.

However, besides the successful scenario of Strategy implementation (the Innovative scenario), the document leaves a margin for a possible Conservative scenario (preservation of the current trends, factors, parameters and conditions of environmental protection, operation of the existing industrial basis for processing, utilization and decontamination of waste without infrastructure development). This aspect appears rather strange, as it implies that the Strategy developers assume its possible failure from the very beginning.

Among the principal goals of the Innovative scenario, we see the following: to raise the share of the utilized and decontaminated waste in the total volume of generated waste from $59.6 \%$ in 2016 to $86 \%$ in 2030 ; to raise the share of MSW sent in processing in the total volume of generated waste from $8.9 \%$ in 2016 to $80 \%$ in 2030; to reduce waste generation by $3.7 \%$ in 2030 versus 2016 .

\footnotetext{
1 Strategiia razvitiia promyshlennosti po obrabotke, utilizatsii i obezvrezhivaniiu otkhodov proizvodstva i potrebleniia na period do $2030 \mathrm{~g}$. [The Industry Development Strategy for Treatment, Recycling and Disposal of Production and Consumption Waste] (2018). Available at: http://static.government. ru/media/files/y8PMkQGZLfbY7jhn6QMruaKoferAowzJ.pdf (accessed 5 February 2020).
}

The authors set themselves the task of modelling the results of Strategy targets implementation with the help of the forecast of the environmental and economic development of the Russian Federation until 2030.

\section{Methods}

By the present moment, environmental protection has accumulated a certain practice of applied forecast modelling. It has been proven that the most suitable method for describing the environmental protection processes is the input-output tables representing reproduction of natural resources, laying out the input and output values. In the 1960-s, U. Ayres, A. Knees and H. Daly, the first authors of the mathematical models describing the relations between ecology and economy, faced the impossibility of implementing such models in practice due to the lack of necessary information (Ayres, Knees, 1969; Daly, 1968). The problem was partially resolved by W. Isard, who tried to find a solution for a similar model and made a significant contribution into its database structure in 1972 (Isard, 1972).

In the years 1970-1973, the father of more sophisticated models of this class, V. Leontief, built an input-output model better suited for practical implementation, with due regard to the environmental protection sector (Leontief, Ford, 1972). The model is based on the recognition of the possibility and necessity to include waste treatment measures (anti-pollution facilities) in the input-output structure. The later works of V. Leontief present more general input-output tables that include processes of treatment of polluting substances as well as the use of the primary natural resources and utilized pollutants by the end consumers.

Leontief-type modelling schemes are widely used by numerous economists in forecasting economic development of countries with due regard to pollution of the environment. Some dynamic input-output models that included environmental protection costs were presented in the works by J. Tsukui and Y. Murakany (Tsukui, Murakany, 1977), based on the regional and national input-outputs of $\mathrm{NO}_{\mathrm{x}}$, $\mathrm{SO}_{\mathrm{x}}$ and solid waste values. There are examples 
of some recent researches in the same sphere (Nansai et al., 2009; Bouwmeester et al., 2010; Marin, 2010). However, the above models are often theoretical and focus on the ecological problems of particular regions. Other than that, little attention is paid to input-output methods when describing problems of generation and accumulation of production and consumption waste.

To carry out our research, we used a dynamic input-output model (DIOM) with an ecological block, developed by the Institute of Economics and Industrial Engineering of SB RAS. The proposed approach is distinguished with the capacity of forecasting volumes of generation, elimination and distribution in the environment of all types of pollutants including production and consumption waste. Besides, the model is adapted to real statistical data provided by Rosstat. A detailed description of the model is put forward in (Gil'mundinov et al., 2011). The forecast calculations for DIOM were based on the following principal hypotheses of the RF economic development over the period till 2030: high oil prices (around $\$ 70$ per barrel of Brent), low exchange rate volatility, growing monetary policy efficiency (lower interest rate), successful import replacement policy, low inflation rate (about 5\% p.a.), growing labour productivity. All of these assumptions will ensure the average annual GDP growth rate over the forecast period at the level of $3-4 \%$.

\section{Results}

Calculations within the ecological block of the DIOM demonstrated that raising the share of used and decontaminated waste to
$86 \%$ by 2030 (under the Innovative scenario of the Strategy) allows reduction of accumulated waste growth rate by the end of the year by over six times (from $6.8 \%$ in 2018 to $1.1 \%$ in 2030 , and $5.3 \%$ in 2030 under the Conservative scenario). Thus, according to the calculations, the overall volume of accumulated production and consumption waste will not decrease (as could be expected by 2030 after implementation of the Strategy), but the growth rate will be lower. The results of the forecast calculations are represented in Fig. 2.

\section{Discussion}

The authors do not consider the Innovative scenario truly innovative (the volume of accumulated waste will continue growing, though at a slower pace). The current state of legislation is not favourable employing such a scenario, requiring working mechanisms for reducing the waste generation capacity of manufacturing processes and increased waste utilization.

Notwithstanding a considerably improved conceptual framework, restructured federal, regional and local waste management authorities, corrected waste management requirements and some other measures, there are many "blank spots" appearing in the ecological legislation. Current legislation still has some flaws concerning waste management, and there are some worth pointing out.

1) We see that the legislative acts that do not contain any specific mechanisms of the fulfilment of the set tasks remain unfeasible.

According to the Federal Law No. 458-FZ of 29.12.2014, all constituent entities of the RF

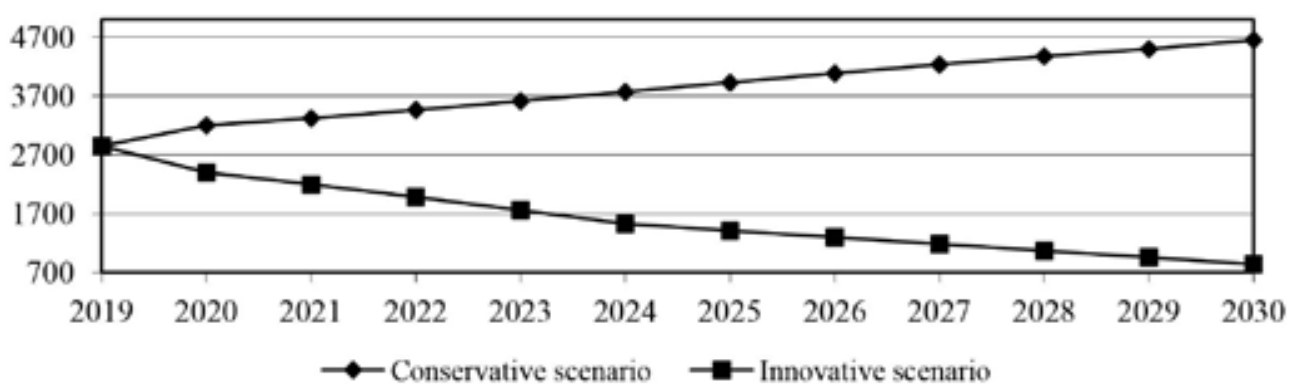

Fig. 2. Forecast dynamics of the waste accumulation annual growth, million tons. Source: forecast calculation results 
were required to adopt a territorial waste management scheme, to identify regional waste management operators and to approve the relevant tariffs for the services of such regional operators by the beginning of 2017. Accumulation, transportation, processing, decontamination, burial in the territory of a constituent entity of the RF had to be assured by the regional operators under the regional waste management program and the territorial scheme. The regional operator needed to sign an agreement with the municipal authorities. In their turn, the solid waste owners had to conclude an MSW management agreement with the regional operator whose territory comprises the municipal solid waste and the places for the accumulation of such.

So, that was the suggested transparent arrangement of MSW management. However, due to some complications that sprang up at the regional level, the date of transition to the new formula shifted to 1 January 2019, while the conditions for conclusion of agreements with de facto operators were seriously modified. This allowed granting the regional operator status to other entities without tenders, therefore creating ample opportunities for public servants to misuse their powers. Registration of uncertified dumps without due control as well as the use of such by the regional operators was also permitted. These circumstances froze the construction of new waste treatment facilities, undermining the investment attractiveness of the industry. Corporations got the right to refuse to make contracts with a regional operator if they had a waste storage site of their own.

The proposed arrangements are dangerous because of the monopoly position of the regional operators they may objectively acquire, as such selection eliminates any competition in the MSW handling. One may thus expect considerable risks for independent companies dealing with sorting and advanced processing of waste. This is likely to undermine the incentives for more efficient processing and burial of MSW, as the costs may be transferred directly to the end consumers. As everyone knows, since the $1^{\text {st }}$ of January 2019, removal and processing of the household wastes has become a separate public service item included in the housing and utility services list, which caused the rise in the waste removal fees.

There are also no mechanisms to encourage the regional operators to observe the decree of the RF Government No. 1589-r of 25.07.2017, which approves the list of production and consumption waste types containing useful components and prohibited to bury. Prohibition of burials is introduced in stages for the years 2018-2021. Compliance with the Decree requires transiting to separate waste collection which is expected only in 2024, and which, in its turn, requires large investments into equipment, as education and enlightenment measures alone would not be sufficient.

As could be expected, most regions are developing the advanced MSW processing and ecological responsibility slowly, as it requires evaluation of the potential and prospects of development with due regard to the ongoing changes and the regional specificity.

By the end of the first quarter of 2018, only 18 regional entities selected 32 regional operators, which started actual operation in five regions only (Babich, 2018: 25). By the beginning of 2019, waste management programs were adopted in 60 regions and territorial schemes were approved in all constituent entities of the RF, but this is not that simple. Thus, in September 2018, the Supreme Court of the Republic of Tatarstan sustained a claim of environmentalists against the adopted territorial scheme. The decision of the Supreme Court overturned the key parts of the document, such as norms of accumulation, flows and conditions of separate MSW collection, location and development of the waste treatment infrastructure (waste burner construction and bottom ash waste range arrangement). Without the above-mentioned parts, the territorial scheme cannot normally function and shall be recognized as non-operational. This is a situation when the Republic appointed the regional operators but they cannot commence their operation due to the invalidity of the territorial scheme. Similar problems occurred in other regions, such as the Transbaikal Territory, the Krasnoyarsk Territory, the Republic of Buryatia, and the Novosibirsk 
Oblast $^{2}$. As the regions are poorly prepared for the reform, the deadline for its launch is said to be delayed in several constituent entities that have not managed to complete the preparatory actions; the deadline is put off to January 1,2020 , and to January 1, 2022, for the federal cities.

2) The size of NIE payments for waste does not cover the waste disposal costs and does not stimulate recycling. According to the current legislation, the payment needs to be done by companies or individuals that produce waste in the course of their economic or other kinds of operation except for municipal solid waste. The municipal solid waste payments are done by the regional operators responsible for disposal. However, this was like this from the start: in 2016-2018 there was a confusion whether it is the enterprise or the regional operator that effects the payment, as the laws contradict each other. Finally, in 2018 the NIE payment for 2016 and 2017 was cancelled (Fil'chenkova, Azueva 2018: 14). Today, those "rushed" environment taxes (since 2019 NIE payments are considered as taxes) for those years are being criticized for being subject to either repayment or recalculation. Such legislative behaviour does not encourage any responsible attitude towards NIE payments as a serious fiscal policy tool that should not be ignored and delayed.

The NIE payment bears a compensatory character, though their size casts doubt as to its adequacy. In particular, those payments can hardly cover reclamation of the lands used as landfills. In 2018, the basic payment rates did not rise despite the annual inflation of $4 \%$. In 2019 , the rates established for 2018 with an insignificant adjustment for $1.04 \%$ were used, although a higher inflation rate was expected.

\footnotetext{
2 Chernykh, K. (2016). 120 milliardov v musor [120 Billion Going Into Waste]. In Kontinent Sibir' [Siberia Continent], 9 September 2016, available at: https://ksonline. $\mathrm{ru} / 238495 / 120$-milliardov-v-musor/

Viktorov, V. (2018). Zarastiom musorom? [About to Get Inundated with Rubbish?]. In Argumenty $i$ fakty [The Arguments and Facts], 22 May 2018, available at: http://www.nsk.aif.ru/ society/zarastem_musorom_pochemu_nevozmozhno_razvitie_musoropererabotki_v_sibiri

Vlasov, Ia. (2018). Musornaia reforma zabuksovala v Sibiri [The Waste Management Reform Failing in Siberia]. In Taiga.info, 18 December 2018, available at: https://tayga. info/ 144190
}

Payments for the contamination hazard class of wastes are close to zero. However, these are mostly technogenic wastes of fuel and energy companies that exert pressure on the environment due to: alienation of land, disruption of natural biogeochemical cycles, emission of dangerous and toxic substances into the air, soil, ground and underground water. According to experts, the negative impact of technogenic wastes is apparent on the territory that exceeds the waste storage space by $10-15$ times. Companies often seek to reclassify the I-IV hazard class wastes into class $\mathrm{V}$ or to certify them as raw materials to save on the NIE payments. Such reclassification is an attractive solution, as it resolves the problem of disposal of wastes to the special sites: I-IV class wastes can only be sold to a licensed organization while those of $\mathrm{V}$ class can be sold to anybody (Al'geshkina, 2018: 61). However, the waste classification criteria are not properly formulated. It is worth pointing out that the legislation is contradictory as to the definition of the waste hazard degree. For example, according to clause 4.1 of the Federal Law No. 89-FZ of 24 June 1998 "About production and consumption waste", wastes are classified into five classes of hazard with the $5^{\text {th }}(\mathrm{V})$ class presenting no danger to the environment. But in the "Sanitary norms for determination of the hazard class of toxic production and consumption waste" SP 2.1.7.1386-03, there is another classification of wastes where the last, $4^{\text {th }}$ (IV) class being "not very hazardous". Thus, two classifications are relying on different data used to appraise the same waste based on different criteria.

3) The waste disposal licensing scope has not been sufficiently clarified. Since the end of 2017, waste transportation has become a separate activity requiring no license (Alymova, 2018: 34). Companies are allowed to collect wastes as well as to do processing, utilization, and decontamination. An economic agent may not do collection or collection with transportation only (Endeko, 2018: 6). Thus, the simultaneous collection and transportation of waste (e.g. 'green' containers for the collection of separate waste transported by the vehicles of the companies that installed them, or collection of wastes in such public spaces as shopping cen- 
tres) has got banned. To evade this ban, such type of activity as "accumulation" was made up, though basically, it stands for collection, as one must collect rubbish first to accumulate it, but requires no license. In its turn, transportation license cancellation is doubtful. as waste transport containers have to meet special requirements to ensure safe transportation. On the other hand, there are not enough arguments for licensing some kinds of waste collection (batteries, pulp paper).

Licensing requirements for stockpiling, processing and sale of scrap iron and non-ferrous metal put considerable restrictions on small businesses. To collect scrap metal, according to the license requirements the company or the individual entrepreneur needs to have a production site, scrap metal processing equipment and a laboratory (not essential for this type of activity). On the other hand, as we have pointed out earlier, there are no licensing requirements for handling $\mathrm{V}$ class wastes, as generation and accumulation of such waste may be damaging and not desirable.

4) There is a need to improve the mechanisms for the ecological and utilization charges collection. In January 2015, the ecological charge part of the Federal Law "About production and consumption waste" (of 24.06.98 No. 89) was amended (see Law No. 458 of 29.12.2014). The money collected as ecological and utilization charges are deposited to the federal budget and then directed to the constituent entities of the Russian Federation as subsidies. Earlier, it was decided to provide the subsidies in proportion to the size of the population; in 2019 this decision was cancelled, and the approach is still not clear. The state retains the right to delay subsidies until the end of products' lifecycle and often uses the money on current expenses not related to waste management. As a result, real subsidies get indefinitely delayed and the municipal waste treatment enterprises get no support, holding back the modernization of the entire industry. So, the existing approach to distribution and spending ecological charge revenues does not help to resolve the problem of waste collection and processing. It is necessary to channel the money collected as ecological charge directly to the companies and regional operators, involved in the disposal of waste. It might be done as compensation for every ton of the collected recycled material.

The ecological charge fee should stimulate the compensatory mechanism because the separation of recycling from the principal technological processes augments the cost of the recycled material. The compensatory mechanism must stimulate the manufacturing of products that are simple to dispose of in the future. It is necessary to stream subsidies to the investment projects within the limits of the charge paid for the products, the lifecycle of which has not yet expired. The ecological charge is expected to become an extra-budgetary fund so that its rise would not only compensate the current expenditures of regional operators and manufacturers but also enhance the recycling industry development as a whole (Koroleva, 2016).

If the utilization charge is obligatory (the charge paid by the vehicle manufacturer or, in some cases, by the imported car owner), the enterprise has no choice (whether to pay the charge or utilize the waste as in case of transportation charge). So, this charge is just an instrument of the protection policy that increases the manufacturing costs. It is not a fiscal stimulus tool for the recycling industry. We believe that the utilization charge should follow the same principle as the ecological charge.

\section{Conclusion}

To sum up, it should be explained that the paper was intended only to point out the main drawbacks in the existing waste management mechanism. There are many more problems, including adjustment of fees (increasing and decreasing coefficients in addition to the ecological tariffs and charges), limiting and standard-setting (standards of waste generation, limits for their localization and disposal values), category setting (assignment of hazard classes), etc. Thus, implementation of the Innovative scenario of the Strategy for developing the waste treatment, utilization and deactivation industry till 2030 requires effective mechanisms of reducing the wastes generated by the production processes. 


\section{References}

Al'geshkina, O.A. (2018). Sertifikatsiia otkhodov kak syr'ia [Certification of Waste as Raw Material]. In Ekologiia proizvodstva [Ecology of Production], 7, 60-65.

Alymova, V.A. (2018). Sbor "ushel", transportirovanie ostalos' [Collection is Over, Transportation Pending]. In Ekologiia proizvodstva [Ecology of Production], 3, 33-39.

Ayres, U., Kneese, A. (1969). Production, Consumption and Externalities. In American Economic Review, 3 (59), 289-298.

Babich, M.E. (2018). Tverdye kommunal'nye othody: ot obiazannosti k otvetstvennosti [Solid Municipal Waste: from Duty to Responsibility]. In Ekologiia proizvodstva [Ecology of Production], 3, 24-28.

Bouwmeester, M., Oosterhaven, J., Duchin, F. (2010). Consumption-Based Environmental Accounting of $\mathrm{CO}_{2}$ Emissions and Water Use in a World-Wide Multi-Regional Input-Output Framework. In Materials of ISEE Conference, Oldenburg, Press of Carl von Ossietzky Oldenburg University, 227.

Daly, H. (1968). On Economics as a Life Science. In The Journal of Political Economy, 3, 392-406.

Endeko, A.I. (2018). Raz'iasneniia ob izmeneniiakh v oblasti obrashcheniia s otkhodami [Explanations of Changes in Waste Management]. In Ekologiia proizvodstva [Ecology of Production], 6, 6-10.

Fil'chenkova, O.A., Azueva, L.M. (2018). Raz'iasneniia po ischisleniiu i vzimaniiu platy pri razmeshchenii otkhodov [Explanations on Calculation and Collection of the Waste Disposal Fees]. In Ekologiia proizvodstva [Ecology of Production], 3, 9-18.

Gil'mundinov, V.M., Kazantseva, L.K., Tagaeva, T.O. (2011). Problemy okhrany vodnykh $i$ atmosfernykh resursov Rossii [Challenges of Aqueous and Air Resources Protection in Russia]. Novosibirsk, IEIE SD RAS, $166 \mathrm{p}$.

Isard, W. (1972). Ecologic-Economic Analysis for Regional Development. N.Y., The Free Press, 270 p.

Koroleva, L.P. (2016). Gde vzyat' den'gi na retsikling? [Where Can We Get Money for Recycling?]. In EKO, 10, 142-155.

Leontief,V., Ford, D. (1972). Mezhotraslevoy analiz vozdeystviia struktury ekonomiki na okruzhaiushchuiu sredu [Intersectoral Analysis of Economic Structure's Impact on the Environment]. In Ekonomika $i$ matematicheskie metody [Economics and Mathematical Methods], 8 (3), 370-399.

Marin, G. (2010). Sector $\mathrm{CO}_{2}$ and SOx Emissions Efficiency and Productivity: Homogeneous and Heterogeneous Estimates using the Italian NAMEA. In Proceedings of ISEE Conference, Oldenburg, Press of Carl von Ossietzky Oldenburg University, 226.

Nansai, K., Kagawa, S., Kondo, Y., Suh, S., Inaba, R., Nakajima, K. (2009). Improving the Completeness of Product Carbon Footprints using a Global Link Input-Output Model: the Case of Japan. In Economic Systems Research, 3(21), 267-290.

Tsukui, J., Murakany, Y. (1977). Turnpike Optimality in Input-Output Systems: Theory and Application for Planning. N.Y., Kluwer Academic Publishers, 217 p. 


\title{
Институциональные реформы в сфере обращения с отходами в РФ
}

\author{
Т.О. Тагаева, В.М. Гильмундинов \\ Новосибирский государственный университет \\ Российская Федерачия, Новосибирск \\ Институт экономики \\ и организачии промышленного производства СО РАН \\ Российская Федерачия, Новосибирск
}

\begin{abstract}
Аннотация. Ситуация в области охраны водных и атмосферных ресурсов оценивается специалистами как стабильно негативная, без явных тенденций к улучшению, имеющая проциклический характер. Чего, к сожалению, нельзя сказать о системе обращения с отходами производства и потребления. Даже в кризисные периоды объемы образующихся и накапливаемых отходов продолжают расти. В 2018 году первый показатель удвоился по сравнению с 2005 годом. Таким образом, актуальность предмета исследования объясняется неблагоприятной экологической обстановкой в России. Целью работы является разработка методологических подходов к ее анализу и прогнозированию. Поставленная цель позволила сформулировать следующие задачи: изучить текущее состояние окружающей среды в сфере обращения с отходами, разработать предпосылки для прогнозирования объемов образования и накопления отходов, оценить экологическую нагрузку на ближайшее будущее. Несмотря на активные усилия по реформированию системы обращения с отходами, предпринятые начиная с 2014 года, российское законодательство в этой области остается несовершенным, противоречивым, лишенным стимулирующих переработку отходов механизмов. Основные недостатки происходящих в данной сфере реформ рассмотрены в статье.
\end{abstract}

Ключевые слова: производство и накопление отходов производства и потребления, твердые коммунальные отходы, рециклинг, утилизация и обезвреживание отходов, природоохранное законодательство.

Работа выполнена по плану НИР ИЭОПП СО РАН, проект XI.170.1.1. «Инновационные и экологические аспекты структурной трансформации российской экономики в условиях новой геополитической реальности», № AAAA-A17-117022250127-8.

Научная специальность: 08.00.05 - экономика и управление народным хозяйством (экономика природопользования). 